\title{
ECOLOGICAL STUDY OF EPIPHYTIC DIATOMS ON TWO SUBMERGED AQUATIC MACROPHYTES IN TIGRIS RIVER, IRAQ \\ S F. Ali ${ }^{1^{*}} \quad$ F M. Hassan $^{2} \quad$ R A. Abdul-Jabar ${ }^{1}$ \\ Researcher Prof. Prof. \\ ${ }^{1}$ Dept. of Biology, Coll. of Sci., Tikrit University. \\ 2 Dept. of Biology, Coll. of Sci. for Women, University of Baghdad. \\ fikrat@csw.uobaghdad.edu.iq
}

\section{ABSTRACT}

This study was aimed to provide the baseline information of epiphytic diatom communities in the Tigris river within Wasit Province to fill the information gap on the algal distribution. This investigation was conducted on epiphytic diatoms from two macrophytes (Ceratophyllum demersum and Myriophyllum alterniflorum) and related physicochemical parameters of the river from June 2015 to May 2016. Three sites were selected along the river (Al-Aziziyah, Zubaidiyah, and Numaniyah). Qualitative and quantitative study of epiphytic diatoms was investigated. A total of 277 species of epiphytic diatoms were identified on both macrophytes, these diatoms belonged to 27 genera for $C$. demersum and 28 genra for M. alterniflorum. A total number of diatom species were ranged from $801.8 \times 10^{4}$ cell.g $^{-1}$ at site 3 to $1159.72 \times 10^{4}$ cell.g ${ }^{-1}$ at 1 for $C$. demersum, while on $M$. alterniflorum were ranged $\left(87.24 \times 10^{4}-545.68 \times 10^{4}\right.$ cell. $\mathrm{g}^{-1}$ ) at site1. The study revealed that diatoms were abundant, reflecting the quality of water and determine the extent of pollution and polluted type.

Keywords: aquatic plants, lotic ecosystem, algae, qualitative and quantitative study.

*Part of Ph.D. Dissertation of $1^{\text {st }}$ author.

علي وآخرون 1119-1109:5(4)50:2019-1اقلة العلوم الزراعية العراقية

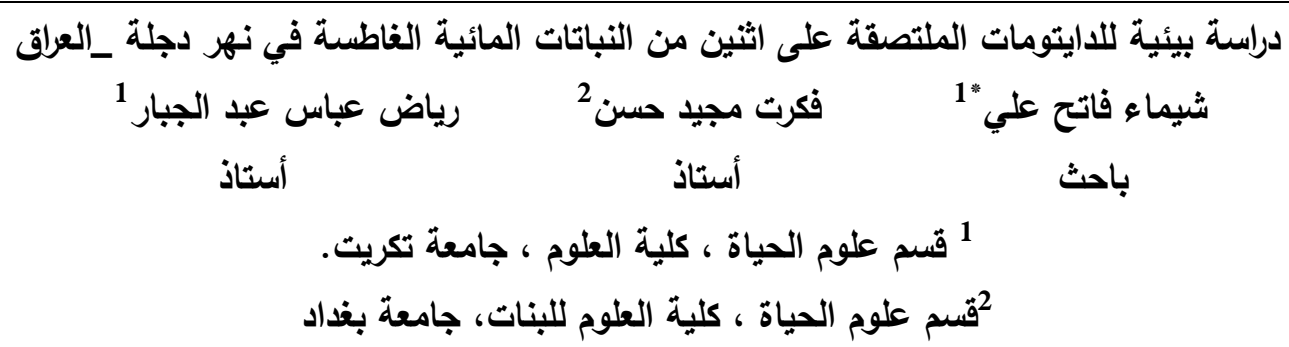

المستخلص

هدفت الدراسة الى توفير المعلومات الأساسية عن المجتمعات الدايتومات الملتصقة في نهر دجلة ضمن محافظة واسط لملع الفجوة في المعلوماتية حول توزيع هذه الطحالب. تناول البحث الدايتومات الملتصقة على اثثين من النباتات المائية وعلاقتها بالعوامل الفيزيائية وإلكيميائية للنهر و (Myriophyllum alterniflorum و Ceratophyllum demersum) للمدة من شهرحزيران 2015 الى شهر آيار 2016. تم اختيار ثلاث مواقع على طول النهر (العزيزية، الزبيدية، النعمانية). وتم دراسة كمية ونوعية الدايتومات الملتصقة. سجلت هذه الدراسة 277 نوعاً من الدايتومات الملتصقة على كلا النباتين وتعود هذه الايتومات الى 27 جنسا بالنسبة لنبات C. demersum و28 alterniflorum Mنسا لنبات

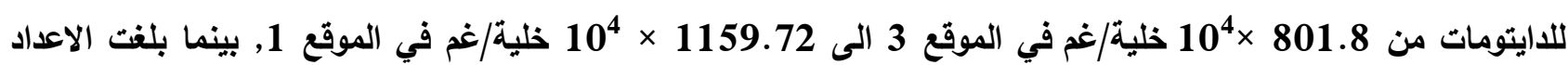
الكلية لدايتومات الملتصقة على نبات M. alterniflorum بين 87.24 × 104 - خلية/غم الى 10 × 545.68 × 10 خلية/غم في في الموقع 1. كثفت الاراسة غزارة صنف الدايتومات مما يعكس نوعية المياه وتحديد مدى و نوع التلوث. الكلمات المفتاحية: الطحالب الملتصقة، النباتات المائية, المياه الجارية, الطحالب، دراسة كمية ونوعية. *زء من اطروحة الاكتوراه للباحث الاول. 


\section{INTRODUCTION}

Aquatic macrophytes form the specific environment by either suppressing or stimulating aquatic organisms, as well as by enhancing the availability of a large area suitable for colonialism and the attached epiphytic community (3). Epiphytic algae are organisms that attach to aquatic macrophytes by secreting mucilage or colonizing on aquatic macrophyte and sediment surfaces, and constitute heavy carbonate accumulations on plant parts (15). Epiphytes are part of the structured community, which contains primary producers and consumers as well as decomposers. Epiphytic diatoms are play a major role in ecological balance between various macrophytes and their environment. Diatoms may be affected by different factors as macrophyte architecture, water depth, seasonal changes, light intensity, $\mathrm{pH}$, temperature and abundance of macrophytes $(4,9,18)$. Epiphytic algae attaches to their hosts in various forms such as encrusting, basal, mucilage, long or short stalk, and pad forms (10). Due to the sensitivity of the benthic algae, they are used as bioindicators to gauge the aquatic environmental conditions (28). The present study aimed to account for epiphytic diatoms on two species of host macrophytes in Tigris River and to fill the knowledge gap in epiphytic diatoms in Wasit province south of Iraq for the first time.

\section{MATERIALS AND METHODS}

Three sites selected along Tigris River in Wasit province (Al-Aziziyah, Zubaidiyah and Numaniyah). The present study was carried out from July 2015 to May 2016 and the results presented seasonally (Fig. 1, Table1). All physicochemical parameters of water were measured according to APHA (13) nitrite, nitrate and phosphate (32) and silicate (26). The aquatic plants were collected from each site and preserved by using $(3 \mathrm{ml})$ of the formalin $4 \%$ as a preservative for a while back to the laboratory. Then the algae separated from the leaves, stems and roots (if it found) of aquatic plant hosts, shaking with scrape to separate the algae from host plant (19), then scrape the surfaces of aquatic plants by brush to ensure the separation of the largest number of algae. Calculated diatom cells by light microscope using an oily compound lens $100 \mathrm{X}$ following the Microtransect method for counting the epiphytic diatom

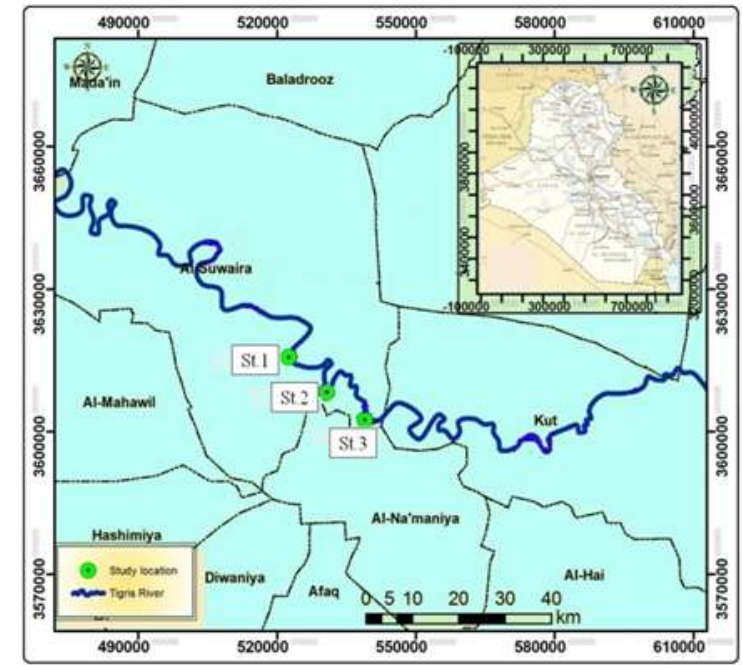

Figure 1. Map of study areas (Used Arc-GIS Map program)

Table 1. The geographical positions (GPS) of the three study sites

\begin{tabular}{|lll|}
\hline Sites & $\begin{array}{c}\text { Longitude } \\
\text { (eastwards) }\end{array}$ & $\begin{array}{l}\text { Latitudes } \\
\text { (northward) }\end{array}$ \\
\hline $\begin{array}{l}\text { St.1: Al- } \\
\text { Aziziyah }\end{array}$ & $\mathbf{3 8}^{\circ} .1835^{\prime}$ & $5^{\circ} .9050^{\prime}$ \\
$\begin{array}{l}\text { St.2: } \\
\text { Zubaidiyah }\end{array}$ & $3^{\circ} .9799^{\prime}$ & $\mathbf{5 5}^{\circ} .8840^{\prime}$ \\
$\begin{array}{l}\text { St.3: } \\
\text { Numaniyah }\end{array}$ & $35^{\circ} .9611^{\prime}$ & $\mathbf{5 7}^{\circ} .7080^{\prime}$ \\
\hline
\end{tabular}
cells (17).

\section{RESULTS AND DISCUSSION}

The results of this study recorded water temperature ranged from $12{ }^{\circ} \mathrm{C}$ to $34{ }^{\circ} \mathrm{C}$. The highest temperatures were recorded in the summer (August 2016) at sites 1 and 3, and the lowest temperature in the winter (February 2016) at sites 1 and 3 (Table 2). 
Table 2. Range, average of physicohemical in the Tigris River during the study period 2015 2016

\begin{tabular}{|c|c|c|c|}
\hline \multirow{2}{*}{ Parameters } & \multicolumn{3}{|c|}{ Sites } \\
\hline & S1 & S1 & S1 \\
\hline Water Temp. $C^{o}$ & $12.00-34.00 \quad 22.62$ & $12.5-33.022 .95$ & $12.0-34.023 .41$ \\
\hline pH & $6.7-8.27 .25$ & $6.7-8.3 \quad 7.19$ & $6.7-8.2 \quad 7.25$ \\
\hline Dissolved oxygen mg. $\mathrm{L}^{-1}$ & $5.2-11.2 \quad 8.0$ & $5.6-11.2$ & $5.2-11.68 .38$ \\
\hline $\mathrm{BOD}_{5} \mathrm{mg} \cdot \mathrm{L}^{-1}$ & 0.4-2.3 1.4 & $0.4-2.5 \quad 1.36$ & $0.3-2.3 \quad 1.27$ \\
\hline Total Hardness $\mathrm{mg} \mathrm{CaCO}_{3} \cdot \mathrm{L}^{-1}$ & $600-1100848.3$ & $600-1000 \quad 795$ & $600-1040840$ \\
\hline Calcium mg CaCO${ }_{3} \cdot \mathrm{L}^{-1}$ & $350-740515$ & $380-725 \quad 472.5$ & $370-770496.2$ \\
\hline Magnesium mg CaCO $3 . \mathrm{L}^{-1}$ & $100-585332.8$ & $75-475 \quad 330$ & $100-500350$ \\
\hline Alkalinity mg CaCO${ }_{3} \cdot \mathrm{L}^{-1}$ & $120-148134.3$ & $114-148 \quad 129.3$ & $114-150130.8$ \\
\hline Nitrite mg. $^{-1}$ & 0.176- $9.76 \quad 2.37$ & $0.134-7.6672 .13$ & $0.153-3.078 \quad 1.04$ \\
\hline Nitrate mg. $^{-1}$ & $0.7-26.217 .04$ & $0.735-26.1716 .63$ & 11.88-26.37 18.07 \\
\hline Phosphate mg. $\mathrm{L}^{-1}$ & $0.039-0.9750 .552$ & $0.026-0.8840 .535$ & $0.052-0.8840 .566$ \\
\hline Silicate $\mathbf{m g . L ^ { - 1 }}$ & 11.94-35.51 25.64 & 11.63-35.81 25.74 & $11.63-34.425 .64$ \\
\hline Sulphate mg. $\mathbf{L}^{-1}$ & 138.4-166.1 158 & 116.7-222.6 155.7 & $119-300162.07$ \\
\hline
\end{tabular}

These results were consistent with other studies $(12,20)$. The results of $\mathrm{pH}$ in the present study ranged 6.7-8.3 (Table 2). The $\mathrm{pH}$ values of Iraq inland water tend to be alkaline in most cases and due to the presence of carbonates and bicarbonates in abundant natural water (27), also the results asymptotic to the study of Al-Janabi (6). The results showed that DO values ranged between 5.2 mg. $1^{-1}$ at sites 1 in June, September2015 and site3 in July, and $11.6 \mathrm{mg} . \mathrm{l}^{-1}$ at sites 3 in February2016. The values of dissolved oxygen were higher than those of some studies on the Tigris River, such as the study of Al-Janabi (6) and Al-Bayati (2). In the present study the water is classified as (clean - very clean) according to the common classification used for water pollution in the UK based on the Biological Oxygen Demand (25). The total alkalinity was affected by many factors such as temperature, decomposition of organic matters and concentration of $\mathrm{CO}_{2}$ (35). The present study showed that the alkalinity values ranged from $114 \mathrm{mg}^{-1}{ }^{-1}$ at site 2 and 3 in August2015 and May2016 to $150 \mathrm{mg} . \mathrm{l}^{-1}$ at site 3 in February 2015.Total hardness were higher than alkalinity values in in the Tigris River and the water in the present study was characterized by its high density and was classified as (33) in terms of hardness as very hardness. This is more common in river water, which is due to the nature of the rock and soil in Iraq (8). This result is higher than that recorded $(2,11)$ Calcium concentrations were higher than magnesium concentrations in the most study periods which may due to the calcium can be attributed to the nature of the land in which the river passes, in which limestone rocks form a large proportion (14). Magnesium tends to precipitate more calcium (20). This is consistent with other studies on the Tigris River that recorded calcium superiority on magnesium, such as $(2,6)$. Calcium values were higher than recorded (11). The nitrite values were recorded 0.134$9.76 \mathrm{mg} . \mathrm{l}^{-1}$ at site 2 in December 2015 and site 1 in July2015 respectively. The decrease in nitrite concentrations may be due to increased consumption by algae and aquatic plants, or due to the lack of polluted flows containing nitrogenous substances and increased rainfall that lead to higher levels of water that led to mitigate. While nitrate ranged 0.71-26.37 mg.l ${ }^{1}$ at site 1 in November2015 and site 3 in April 2016. The highest concentration of nitrates is due to excessive irrigation after the fertilization of the agricultural lands (7). Phosphorus concentrations showed a significant increase that may be a result of high water levels (31). Iraq waters are characterized by high concentrations of silicate. This is due to the geological nature of the land in which Tigris and Euphrates Rivers flow, and they are of great importance for diatoms as they are needed for building of their siliceous skeletons $(16,29)$. And decrease of sulphate concentrations due to their consumption by algae and aquatic plants or to the mitigation factor resulting from high water levels (22). The results of quantitative and qualitative of epiphytic diatoms on two species of macrophyta (C. demersum and $M$. Alterniflorum) were shown in Table 3 and 4. Aquatic plants act as a key ecological role by providing shelter, substrate, and nutrient source for epiphytic algae, which are 
dominants isolates in lotic systems (9). The distribution of algae may be affected by different factors as macrophyte morphology, water depth, seasonal changes, light intensity, $\mathrm{pH}$, temperature and abundance of macrophytes as well as the age of the host plant (18). The study was recorded 227 species of epiphytic diatoms on both macrophytic species in this study. The result showed a number of epiphytic diatoms on Ceratophyllum demersum diagnosed during the study on the Tigris River in three sites 127 species belonging to 27 genera, where the number of central diatoms 11 species belong to 5 genera by $(8.66 \%)$ of the total species.

The number pinnate diatom has reached 116 species belong to 22 genera by $(91.33 \%)$ of the total species (Table 3, 4). The number of epiphytic species classified in site1 is 114 species, the site 2 is 119 species, and the site 3 is 115 species (Table 3). Diatoms are dependent on a variety of different adhesions of different species, such as: Rhicosphenia and Gomphonema have a long and short stalk that helps them to stick. Bacillaria paxillifer cell are joined by mucus produced by the raphe groove, and the genus Synedra contains Mucilage pads form, while the genera of Navicula and Nitzschia bind cell together in a mucous membrane, mucilaginous tube form (5).

Table3. Number of genera and species of diatoms algae and the percentage of epiphytic diatoms on (Ceratophyllum demersum) diagnosed during the study period in the Tigris River

\begin{tabular}{|c|c|c|c|c|c|c|}
\hline \multirow[t]{3}{*}{ Types of Diatoms } & \multicolumn{6}{|c|}{ Sites } \\
\hline & \multicolumn{2}{|c|}{ S1 } & \multicolumn{2}{|c|}{ S2 } & \multicolumn{2}{|c|}{ S3 } \\
\hline & $\mathbf{C}$ & $\mathbf{P}$ & $\mathbf{C}$ & $\mathbf{P}$ & $\mathbf{C}$ & $\mathbf{P}$ \\
\hline Species & 11 & 103 & 12 & 107 & 11 & 104 \\
\hline Genus & 5 & 18 & 5 & 22 & 5 & 24 \\
\hline Percentage of Species \% & 8.87 & 90.35 & 10.08 & 89.91 & \multirow{2}{*}{\multicolumn{2}{|c|}{$\begin{array}{lll}9.00 & 115^{90.4}\end{array}$}} \\
\hline Total number of Species & \multirow{2}{*}{\multicolumn{2}{|c|}{$\begin{array}{c}114 \\
23\end{array}$}} & \multicolumn{2}{|c|}{119} & & \\
\hline Total number of Genus & & & & & & \\
\hline
\end{tabular}

$\mathrm{C}=$ Centric diatom, $\mathrm{P}=$ Pennate diatom The diatoms are adherent to the aquatic plants (9), species Navicula, Nitzschia, Cymbella and As well as the dominance of the pinnate Surirella have the most variety of species, with diatoms on the central diatoms. The results different sites and seasons. Most of these agree with $(5,11,30)$

Table 4. List of epiphytic diatom (Ceratophyllum demersum \& Myriophyllum alterniflor and its total number $\left(\right.$ cell $\left.\times 10^{4} . \mathrm{L}^{-1}\right)$ during the study period. $(-)=$ Type does not exist

\begin{tabular}{|c|c|c|c|c|c|c|}
\hline \multirow[b]{2}{*}{ Diatoms } & \multicolumn{2}{|c|}{ C. demersum } & \multicolumn{4}{|c|}{ M. alterniflorum } \\
\hline & & & & & & \\
\hline Centrales & S1 & S2 & S3 & S1 & S2 & S3 \\
\hline $\begin{array}{c}\text { Aulacoseira granulata (Ehr.) } \\
\text { Simonsen }\end{array}$ & 0.12 & 0.5 & 0.55 & 0.39 & 0.91 & 28.46 \\
\hline A. italica (Ehr.) Simonsen & 0.4 & 0.12 & 0.08 & 0.08 & 0.05 & 0.23 \\
\hline Coscinodiscus granii L.F.Gough & 1.02 & 2.69 & 0.13 & 3.14 & 6.2 & 0.07 \\
\hline Cyclotella atomus Hustedt & 0.19 & 0.27 & 0.29 & 0.1 & 2.28 & 1.22 \\
\hline C. comta Kützing & 0.26 & 0.34 & - & 19.46 & 0.31 & 8.85 \\
\hline C. meneghiniana Kützing & 2.43 & 0.95 & 2.29 & 13.73 & 2.94 & 0.08 \\
\hline C. ocellata Pantocsek & 0.32 & 0.11 & 0.04 & 2.19 & - & - \\
\hline Melosira granulate (Ehr.) Ralfs & 0.28 & 1.42 & 1.04 & 0.97 & 4.2 & 36.1 \\
\hline M. italica (Ehr.) Kützing & 0.06 & 0.08 & 2.09 & 1.75 & 2.12 & 1.28 \\
\hline M. varians Agardh & 0.5 & 3.78 & 3.67 & 15.01 & 1.97 & 51.5 \\
\hline $\begin{array}{c}\text { Thalassiosira baltica (Grunow) } \\
\text { Ostenfeld }\end{array}$ & 0.22 & 0.2 & 0.63 & 0.36 & 1.8 & 1.28 \\
\hline $\begin{array}{c}\text { Total of Centrales } \\
\text { Pennales }\end{array}$ & 5.8 & 11.3 & 10.81 & 57.18 & 22.78 & 129.07 \\
\hline $\begin{array}{l}\text { A. minutissima var. affinis } \\
\text { (Grunow) Lange-Bertalot }\end{array}$ & 6.73 & 19.33 & 0.78 & 22.94 & 35.92 & 10.05 \\
\hline A. acutiuscula Kützing & - & - & - & - & - & - \\
\hline $\begin{array}{c}\text { Amphora elliptica (Agardh) } \\
\text { Kützing }\end{array}$ & - & - & - & - & 1.3 & - \\
\hline A. bioculata Cleve & 1.03 & 0.31 & 0.44 & 4.85 & 10.9 & 33.17 \\
\hline
\end{tabular}




\begin{tabular}{|c|c|c|c|c|c|c|}
\hline A. ovalis (Kütz) Kützing & 21.47 & 0.17 & 3.79 & 0.17 & 28.5 & 27.6 \\
\hline $\begin{array}{c}\text { A. pediculus (Kütz) Grunow ex } \\
\text { A.Schmidt }\end{array}$ & 0.11 & - & 0.4 & - & 0.38 & 0.21 \\
\hline $\begin{array}{l}\text { A. robusta Gregory } \\
\text { Pennales }\end{array}$ & 3.3 & - & 7.17 & 0.06 & 0.15 & 4.44 \\
\hline Achnanthes affinis Grunow & 13.58 & 15.89 & 1.59 & 6.48 & 1.57 & 2.56 \\
\hline A. linearis (W. Smith) Grunow & 0.31 & 0.51 & 0.35 & 0.07 & 1.52 & 0.47 \\
\hline A. minutissima & 25.41 & - & 0.31 & - & 0.1 & 4.54 \\
\hline $\begin{array}{l}\text { B. paxillifera (O.F.Müller) } \\
\text { T.Marsson }\end{array}$ & & 7.08 & 0.26 & 4.7 & 2.42 & 0.54 \\
\hline $\begin{array}{c}\text { Caloneis amphisbaena(Bory.) } \\
\text { Cleve }\end{array}$ & 103.18 & $\mathbf{7 3 . 6}$ & 70.6 & 33.6 & 69.2 & 55 \\
\hline $\begin{array}{l}\text { C. amphisbaena var. subsalina } \\
\text { (Donkin) Cleve }\end{array}$ & 75 & 79.9 & 31.5 & 33.2 & 22.04 & 50.3 \\
\hline C. bacillum (Grunow) Cleve & 0.28 & 0.91 & 0.13 & 1.73 & 23.38 & 5.07 \\
\hline $\begin{array}{l}\text { Cocconeis pediculus Ehrenberg } \\
\text { C. placentula Ehrenberg }\end{array}$ & $\begin{array}{r}27.7 \\
50.97\end{array}$ & $\begin{array}{r}20.77 \\
83.4\end{array}$ & 2.17 & $\begin{array}{r}19.1 \\
55.43\end{array}$ & 0.08 & $\begin{array}{l}5.96 \\
581\end{array}$ \\
\hline $\begin{array}{c}\text { C. placentula var. euglypta (Ehr.) } \\
\text { Cleve }\end{array}$ & 49.66 & 94.2 & 88.54 & 38.66 & 30.26 & 51 \\
\hline
\end{tabular}

Table 4. Continuum

\begin{tabular}{|c|c|c|c|c|c|c|}
\hline \multirow[b]{2}{*}{$\begin{array}{l}\text { Diatoms } \\
\text { Centrales }\end{array}$} & \multicolumn{3}{|c|}{ C. demersum } & \multicolumn{3}{|c|}{ M. alterniflorum } \\
\hline & S1 & $\mathbf{S 2}$ & S1 & Sites & S1 & $\mathbf{S 2}$ \\
\hline $\begin{array}{l}\text { Cymatopleura elliptica } \\
\text { (Brébisson) W.Smith }\end{array}$ & - & 0.25 & - & - & 9.54 & - \\
\hline C. solea (Breb.) W.Smith & 4.6 & 7.82 & 0.06 & 20.85 & 5.27 & 1.25 \\
\hline Cymbella affinis Kützing & 42.23 & 10.76 & 0.42 & 18.37 & 6.09 & 32.6 \\
\hline C. aspera (Ehr.) Cleve & 11.67 & 22.2 & 0.42 & 0.32 & 3.25 & 2.3 \\
\hline C. cistula(Hemp.) Grunow & 0.32 & 22 & 1.45 & 8.26 & - & 0.1 \\
\hline C. cymbiformis C.Agardh & 0.2 & 0.95 & 0.1 & - & 10.9 & 0.19 \\
\hline $\begin{array}{l}\text { C. lanceolata (C.Agardh) } \\
\text { Kirchner }\end{array}$ & 26.92 & 0.25 & 0.1 & 7.13 & - & 17.9 \\
\hline C. lange-bertalotii Krammer & 0.41 & 1.1 & 0.24 & - & - & 2.74 \\
\hline C. prostrate (Berk.) Cleve & 2.71 & 16.43 & - & 2.35 & - & - \\
\hline C. tumida (Breb.) Van.Heurck & 20.64 & 0.91 & 11.01 & - & 10.79 & 0.18 \\
\hline C. turgida (Greg.) Cieve & - & 6.58 & - & 11.34 & 1.86 & 7.36 \\
\hline Diatoma vulgare Bory & 0.53 & 0.17 & 3.68 & 2.8 & 29.13 & 1.62 \\
\hline D. moniliforme Kützing & 0.08 & $\mathbf{0 . 0 8}$ & 0.21 & 0.2 & 9.1 & 0.66 \\
\hline $\begin{array}{l}\text { Encyonema silesiacum } \\
\text { (Bleisch) D.G.Mann }\end{array}$ & 0.02 & 1.63 & 0.19 & 0.13 & 15.82 & 11.7 \\
\hline $\begin{array}{c}\text { Eunotia exigua (Brébisson ex } \\
\text { Kütz.) Rabenhorst }\end{array}$ & 7.53 & $\mathbf{0 . 3 5}$ & 0.12 & 0.14 & 0.14 & 0.22 \\
\hline E. fallax A.Cleve & - & - & 0.1 & - & - & 0.09 \\
\hline E. minor (Küitz.) Grunow & 0.08 & 0.68 & 0.37 & 2.2 & 0.14 & 2.4 \\
\hline Fragilaria biceps Ehrenberg & 0.86 & 0.04 & 2.83 & 10.78 & 2.78 & 2.72 \\
\hline F. capucina Desmazieres & 1.48 & 0.96 & - & 0.89 & 12.39 & - \\
\hline $\begin{array}{c}\text { F. capucina var. rumpens } \\
\text { (Kütz.) Lange-Bertalot ex } \\
\text { Bukhtiyarova }\end{array}$ & 0.08 & 2.52 & 0.2 & 0.34 & 4.64 & 0.06 \\
\hline F. construens (Ehr.) Grunow & 0.18 & 0.24 & 4.5 & 0.41 & 16.7 & 0.32 \\
\hline $\begin{array}{c}\text { F. construens } f . \text { binodis (Ehr.) } \\
\text { Hustedt }\end{array}$ & 2.58 & 7.98 & 2.7 & 0.22 & 0.2 & 0.58 \\
\hline F. crotonensis Kitton & 0.57 & $\mathbf{0 . 3 3}$ & 0.35 & 2.34 & 31.3 & 0.24 \\
\hline
\end{tabular}


Ali \&et al.

\begin{tabular}{|ccccccc|}
\hline F. elliptica Schumann & - & 0.83 & 9.12 & 4.53 & 0.74 & 0.17 \\
$\begin{array}{c}\text { F. } \text { intermedia Grunow } \\
\text { F. ulna (Nitzsch) Lange- }\end{array}$ & 0.21 & 7.22 & 0.18 & 0.08 & 9.02 & 0.11 \\
$\begin{array}{c}\text { Bertalot } \\
\text { F.ulna var. acus (Kütz.) } \\
\text { Lange-Bertalot }\end{array}$ & - & 91.6 & 0.63 & 24.1 & 0.17 & 21.92 \\
$\begin{array}{c}\text { F. ulna var. biceps (Kütz.) } \\
\text { Compère }\end{array}$ & 0.07 & 16.6 & 34.48 & 57.1 & 77.8 & 37.2 \\
\hline
\end{tabular}

Table 4. Continuum

\begin{tabular}{|c|c|c|c|c|c|c|}
\hline \multirow{4}{*}{$\begin{array}{c}\text { Diatoms } \\
\text { Centrales }\end{array}$} & \multicolumn{3}{|c|}{ C. demersum } & \multicolumn{3}{|c|}{ M. alterniflorum } \\
\hline & \multicolumn{6}{|c|}{ Sites } \\
\hline & S1 & S2 & S1 & $\mathbf{S 2}$ & S1 & $\mathbf{S 2}$ \\
\hline & & & & & & \\
\hline Gomphoneis olivecum (Horne) & 32.34 & 1.9 & $\mathbf{0 . 3 5}$ & 21.23 & 37.4 & 4.48 \\
\hline P.Dawson ex. Ross et Simith & 52.54 & 1.9 & 0.00 & 210.20 & דים & \\
\hline Gomphonema acuminatum Ehrenberg & 6.38 & 1.78 & 31 & 38.7 & 5.97 & 1.87 \\
\hline G. affine Kützing & 12.7 & 2.29 & 28.98 & - & - & 0.41 \\
\hline $\begin{array}{l}\text { G. exilissimum (Grunow) Lange- } \\
\text { Bertalot \& E.Reichardt }\end{array}$ & 0.07 & 0.54 & 0.62 & - & 0.22 & 0.27 \\
\hline G.geminatum (Lyngbye) C.Agardh & 13.23 & 33.5 & 13.23 & - & 0.14 & - \\
\hline G. insignaffine E.Reichardt & 46 & 1.22 & 46.92 & 29.06 & 58.77 & 1.95 \\
\hline G. lagenula Kützing & 0.07 & - & 0.5 & - & - & 0.08 \\
\hline G. minuta P.Fusey & 4.92 & 2.5 & 7.82 & 3.7 & 36.5 & 25.3 \\
\hline G. minutum (C.Agardh) C.Agardh & 21.6 & 0.16 & 2.88 & 29.64 & 63.7 & 19.38 \\
\hline G. olivaceum (Hornemann) Brébisson & 11.54 & & - & 0.43 & 29.43 & 60.4 \\
\hline G. parvulum (Kütz.) Kützing & 44.42 & 27.6 & 20.26 & 12.22 & 55.9 & 12.03 \\
\hline G. parvulum var exilissimum Grunow & 0.21 & 0.06 & - & 0.54 & 1.83 & 2.23 \\
\hline $\begin{array}{c}\text { G. pumilum var. elegans E.Reichardt } \\
\text { \& Lange-Bertalot }\end{array}$ & 0.26 & 1.74 & 0.04 & $\mathbf{0 . 0 8}$ & 0.52 & - \\
\hline G. rhombicum Fricke & 0.02 & 0.15 & 0.11 & 3.27 & 0.07 & - \\
\hline G. truncatum Ehrenberg & 5.26 & 7.93 & 2.32 & 7.04 & 8.95 & $\mathbf{0 . 3 3}$ \\
\hline $\begin{array}{c}\text { Gyrosigma acuminatum (Kütz.) } \\
\text { Rabenhorst }\end{array}$ & 1.77 & 0.24 & 0.19 & 7.96 & 10.57 & 2.02 \\
\hline G. attenuatum (Kütz.) Rabenhorst & 0.26 & 1.59 & 0.2 & 2.14 & 20.05 & 0.56 \\
\hline $\begin{array}{c}\text { G. fasciola (Ehr.) J.W.Griffith \& } \\
\text { Henfrey }\end{array}$ & 0.17 & - & 3.55 & - & 0.13 & 0.19 \\
\hline Hantzschia amphioxys (Ehr.) Grunow & - & - & - & 3.9 & - & - \\
\hline 0.12 & 0.58 & 2.25 & 0.1 & 0.05 & 2.31 & \\
\hline Navicula ambigua Ehrenberg & - & 0.47 & 0.46 & 1.29 & 1.3 & 5.04 \\
\hline $\begin{array}{l}\text { N. capitata var. hungarica (Grunow) } \\
\text { R.Ross }\end{array}$ & 0.11 & 0.22 & 0.11 & - & - & - \\
\hline N. cryptocephala Kützing & 21.45 & 1.79 & 0.21 & $\mathbf{0 . 0 3}$ & - & - \\
\hline N. cuspidata (Kutz.) Kutzing & 30.78 & 52.5 & $\mathbf{7 . 3 3}$ & 4.32 & 0.06 & 0.08 \\
\hline N. gregaria Donkin & 60.5 & 25.83 & 26.36 & 14.05 & 0.07 & 7.4 \\
\hline N. halophila (Grun.) Cleve & 38.9 & 40.98 & 25.41 & 53.3 & 101.1 & 66.64 \\
\hline N. lanceolata Ehrenberg & 1.7 & 11.17 & 0.14 & 49.53 & 118.3 & 75.2 \\
\hline$N$. protracta Grunow & 0.07 & - & 0.06 & 0.72 & 0.26 & 1.25 \\
\hline N. pygmaea Kützing & 1.32 & 0.15 & $\mathbf{0 . 0 8}$ & 3.6 & - & - \\
\hline$N$. radiosa Kützing & 21.47 & 73.4 & - & 5.8 & $\mathbf{0 . 0 3}$ & 0.08 \\
\hline N. rhynchocephala Kützing & 0.49 & 0.08 & 23.6 & 55.34 & 106.49 & 41.33 \\
\hline N. tripunctata (O.F.Müller) Bory & 0.09 & 0.22 & & 0.06 & 0.05 & 0.08 \\
\hline N. veneta Kützing & 22.91 & 0.44 & 1.15 & 0.04 & 0.06 & 0.2 \\
\hline N. viridis (Nitzsch) Ehrenberg & 0.3 & 38.57 & 45.06 & 0.22 & 25.28 & 14.99 \\
\hline Nitzschia acicularis (Kütz.) W.Smith & 0.68 & 1.68 & 0.3 & 11.58 & 105.05 & 42.6 \\
\hline N. amphibia Grunow & 0.05 & 5.62 & 0.3 & 9 & 22.03 & 12.7 \\
\hline N. capitellata Hustedt & 0.15 & 0.06 & - & 1.81 & 1.45 & 0.08 \\
\hline N. commutate Grunow & - & - & - & 0.05 & 0.29 & 0.04 \\
\hline N. constricta (Gregory) Grunow & 7.62 & 2.57 & 0.34 & 2.37 & 0.21 & - \\
\hline
\end{tabular}


Table 4. Continuum

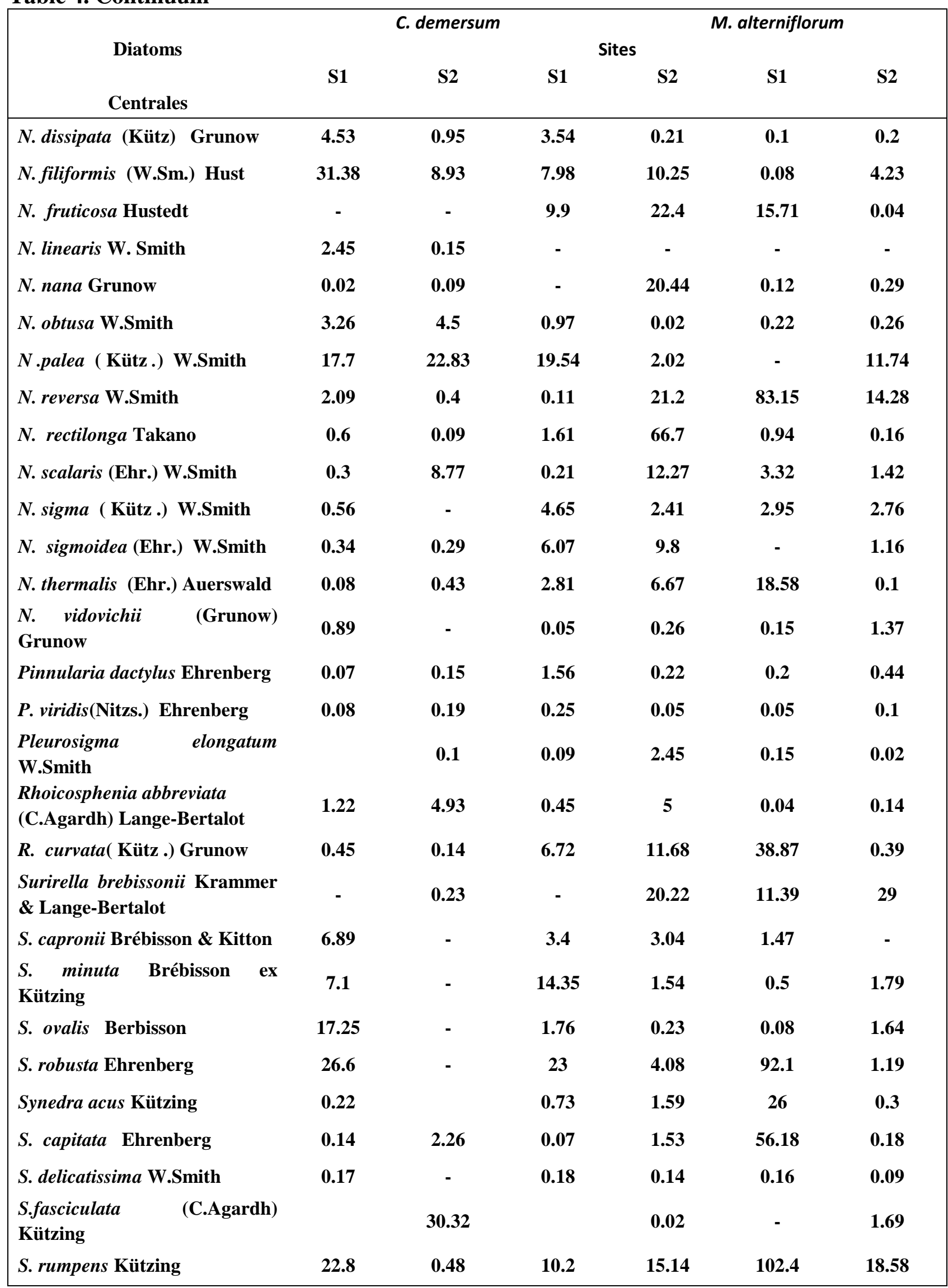


Table 4. Continuum

\begin{tabular}{|c|c|c|c|c|c|c|}
\hline \multirow{2}{*}{$\begin{array}{l}\text { Diatoms } \\
\text { Centrales }\end{array}$} & \multicolumn{3}{|c|}{ C. demersum } & \multicolumn{3}{|c|}{ M. alterniflorum } \\
\hline & S1 & S2 & S1 & $\begin{array}{ll}\text { Sites } & \\
& \text { S2 }\end{array}$ & S1 & S2 \\
\hline S. ulna (Nitzs.) Ehrenberg & 6.87 & 4.59 & 5.5 & 3.62 & 38.1 & 0.1 \\
\hline $\begin{array}{l}\text { S. ulna var. biceps (Kütz.) } \\
\text { Schönfeldt }\end{array}$ & 0.55 & 0.1 & 0.21 & 0.55 & 0.09 & 4.33 \\
\hline Total of Pennales & 1153.92 & 1109.73 & 801.8 & 1056.36 & 1841.5 & 980.49 \\
\hline Total $\left(\right.$ Cell $\left.\times 10^{4} / \mathrm{cm}^{2}\right)$ & 1159.72 & 1121.03 & 812.61 & 1113.54 & 1864.28 & 1109.56 \\
\hline
\end{tabular}

There was a variation in the number of epiphytic diatoms species on Ceratophyllum demersum of the study sites because of the different nature of the influences that are subject to each site. Whereas the number of epiphytic diatoms on Myriophyllum alterniflorum diagnosed 117 species belonging to 28 genera, where the number of central diatoms 11 species belong to 5 genera by $(9.40 \%)$ of the total species. The number pinnate diatom has reached 106 species belong to 23 genera by $(90.59 \%)$ of the total species (Table 5). The number of species classified in site 1 is 124 species, the site 2 is 113 species, the site 3 is 113 species as show in Table 4 and

5. Lowe (24) pointed out that these diatoms

are present in large numbers in basal water and rich in the concentration of nutrients, and the decrease of diatoms may be due to the increased deposition of calcium carbonate $\left(\mathrm{CaCO}_{3}\right)$ on the leaves of aquatic plants due to high temperature (36). Total number of epiphytic diatoms species on Ceratophyllum demersum with different sites and seasons ranged $801.8 \times 10^{4}$ cell.gm ${ }^{-1}-1159.72 \times 10^{4}$ cell.gm $^{-1}$ in sites 3 and site 1 respectively (Table 4). Seasonal variation of the total number of epiphytic daitoms species was observed in this study. For centric diatoms ranged $0.33-28.11 \times 10^{4}$ cell.gm ${ }^{-1}$ at site 1 in winter2016 and Autum2015 respectively.

Table 5. Number of genera and species of diatoms algae and the percentage of epiphytic diatoms (Myriophyllum alterniflorum) diagnosed during the study period in the three sites in the Tigris River

\begin{tabular}{|c|c|c|c|c|c|c|}
\hline Sites & \multicolumn{2}{|c|}{ S1 } & \multicolumn{2}{|c|}{ S2 } & \multicolumn{2}{|c|}{ S3 } \\
\hline Types of Diatoms & $\begin{array}{r}\text { Central } \\
\text { diatoms }\end{array}$ & $\begin{array}{l}\text { Pinnate } \\
\text { diatoms }\end{array}$ & $\begin{array}{l}\text { Central } \\
\text { diatoms }\end{array}$ & $\begin{array}{l}\text { Pinnate } \\
\text { diatoms }\end{array}$ & $\begin{array}{l}\text { Central } \\
\text { diatoms }\end{array}$ & $\begin{array}{l}\text { Pinnate } \\
\text { diatoms }\end{array}$ \\
\hline Species & 11 & 113 & 10 & 103 & 10 & 103 \\
\hline Genus & 5 & 22 & 5 & 22 & 5 & 21 \\
\hline Percentage of Species \% & 8.87 & 91.12 & 8.84 & 91.15 & 8.84 & 91.15 \\
\hline Total number of Species & \multicolumn{2}{|c|}{124} & \multicolumn{2}{|c|}{113} & \multicolumn{2}{|c|}{113} \\
\hline Total number of Genus & \multicolumn{2}{|c|}{27} & \multicolumn{2}{|c|}{27} & \multicolumn{2}{|c|}{26} \\
\hline
\end{tabular}

While the total number of pinnate diatoms ranged $57.79-434.8 \times 10^{4}$ cell.gm $^{-1}$ at site 1 in winter 2016 and summer 2015 respectively. Whereas the total number of epiphytic diatoms species on Myriophyllum alterniflorum ranged $87.24 \times 10^{4}-545.68 \times 10^{4}$ cell.gm $^{-1}$ at site 1 in winter2016 (Table 4). The total number of central diatoms among the sites ranged $0.45-$ $45.26 \times 10^{4}$ cell.gm ${ }^{-1}$ at sites 3 and 1 in spring2016 and summer2015 respectively, and pinnate diatoms ranged $84.99-542.16 \times 10^{4}$ cell.gm ${ }^{-1}$ at sites 1 and 2 in winter2016 and summer2015 respectively. Some species of pinnate diatoms were characterized by the highest number of individuals between sites of the study such as the genus of Navicula radiosa $\left(0.98 \times 10^{4}-36.7 \times 10^{4}\right.$ cell.gm $\left.{ }^{-1}\right)$ at site 2 in summer2015 and winter2016. While Navicula halophile recorded $\left(9.8 \times 10^{4}-36.4\right.$ cell $\times 10^{4}$ cell.gm $\left.^{-1}\right)$ in site2 in summer2015 and winter2016 respectively. Also Some species of central diatoms were characterized by the highest number of individuals between sites of the study such as the genus of Melosira varians $\left(2.3 \times 10^{4}-17.7 \times 10^{4}\right.$ cell.gm ${ }^{-1}$ ) at site3 in spring2016 and the winter2016. While Melosira granulata recorded $6.3 \times 10^{4}-12.2 \times 10^{4}$ cell.gm ${ }^{-1}$ ) at site 3 in summer2015 and in summer2016 respectively. The decrease in the rate of algae is due to several factors, such as grazing rate and flow velocity, turbidity causing 
insufficient light access to photosynthesis (21, $34)$ or due to the lack of nutrient concentrations as a result of the reduction of high water levels, which prevents the growth of algae on the bottom well (1). CCA analysis (Fig.2) shows effect of different environmental factors in the aquatic environment is heterogeneous in the distribution and spread of epiphytic diatoms on Ceratophyllum demersum as results revealed a positive correlation among some epiphytic diatoms N.reversa, A.veneta, C.amphisbaena F.ulna, C.tumida ,S.robusta and environmental factors $\mathrm{Ph}, \mathrm{Ca}^{+2}, \mathrm{Mg}^{+2}, \mathrm{DO}, \mathrm{T}$. Kalinity and $\mathrm{SiO}_{3}{ }^{-}$. While these species are negatively correlated with the environmental factors of
Water temperature and $\mathrm{BOD}_{5}$. Whereas Cocconeis placentula, Cocconeis placentula var.euglyptra, N.halophila, $N$. gregaria $F$. ulna var acus, M.varians, A. bioculata, A. veneta $A$. ovalis and C.affinis have positive correlation with $\mathrm{SO}_{4}^{-2}$ and $\mathrm{NO}_{3}^{-}$, and negative with other studied factors. Whereas N.radiosa, N.palea, A. A.minutissima, G.minutum and S.acus have positive correlation with Water temperature and $\mathrm{BOD}_{5}$ negative with other studied factors. And the genera of F.ulna var acus, $C$. tumida, S. rumpens S.ovalis and G.paravulum have positive correlation with $\mathrm{NO}_{2}{ }^{-}$and $\mathrm{PO}_{4-}{ }^{3}$ and negative with other studied factors.

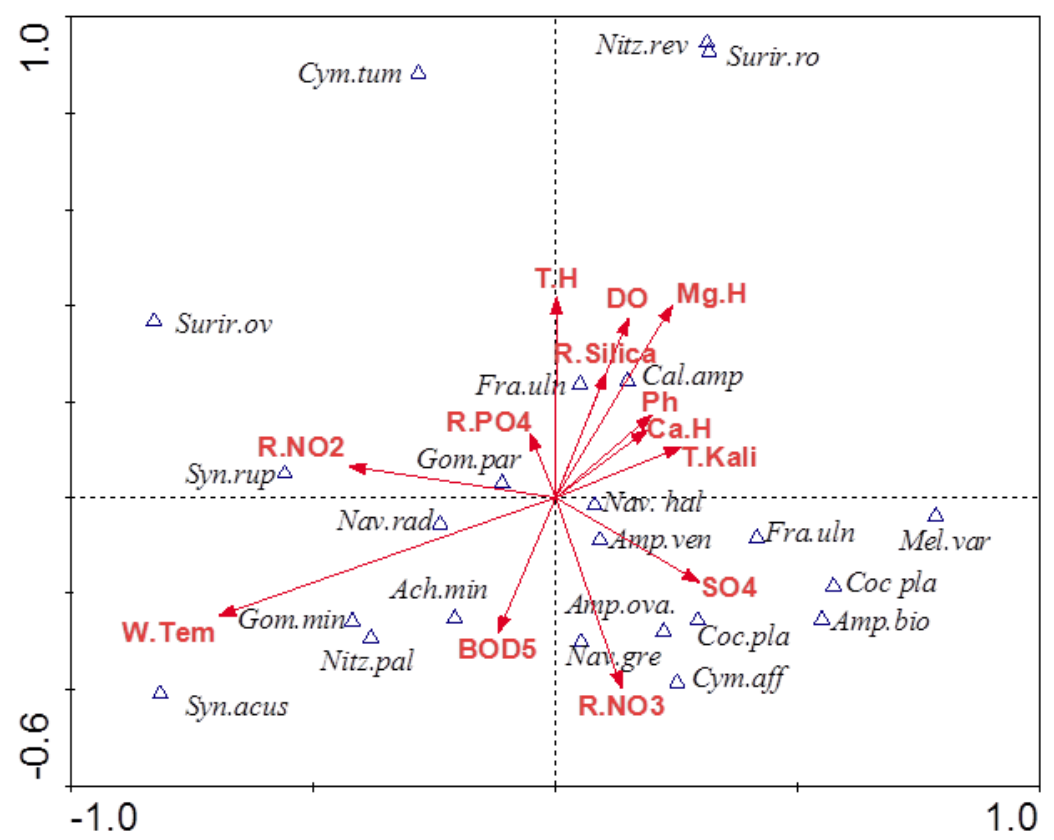

Figure 2. CCA analysis of epiphytic diatoms on (Ceratophyllum demersum) and the environmental correlations during the study period of the Tigris river

While CCA analysis (Fig. 3) of epiphytic diatoms on Myriophyllum alterniflorum as results showed positive correlation among epiphytic diatoms $C$. placentula, C.meneghiniana, S. rumpens, A.affinis and environmental factors T. hardness, $\mathrm{SO}_{4}{ }^{-2}$ and $\mathrm{NO}_{2}^{-}$. While these species are negatively correlated with the environmental factors of $\mathrm{pH}$ and $\mathrm{PO}_{4}{ }^{-3}$. Whereas N.palea, N. filiformis, N. gregaria, A. ovalis and S.robusta have positive correlation with water temperature, $\mathrm{NO}_{3}{ }^{-}, \mathrm{BOD}_{5}$ and Total Alkalinity and negative with other studied factors. And A. bioculata,
$N$. halophile, $F$. ulna and $C$. amphisbaena have positive correlation with $\mathrm{pH}$ and $\mathrm{PO}_{4}{ }^{-3}$. Whereas C. tumida and G. olivaceum positive correlation with $\mathrm{Ca}^{+2}, \mathrm{Mg}^{+2}, \mathrm{DO}$ and $\mathrm{SiO}_{3}{ }^{-}$. The studied physicochemical parameters confirmed that effect of different environmental factors for distribution and spread of epiphytic diatoms on two submerged macrophyte plants of the study sites (23), also seasonal water level variations were playing important roles as limited factors for the distribution and density of epiphytic diatoms 


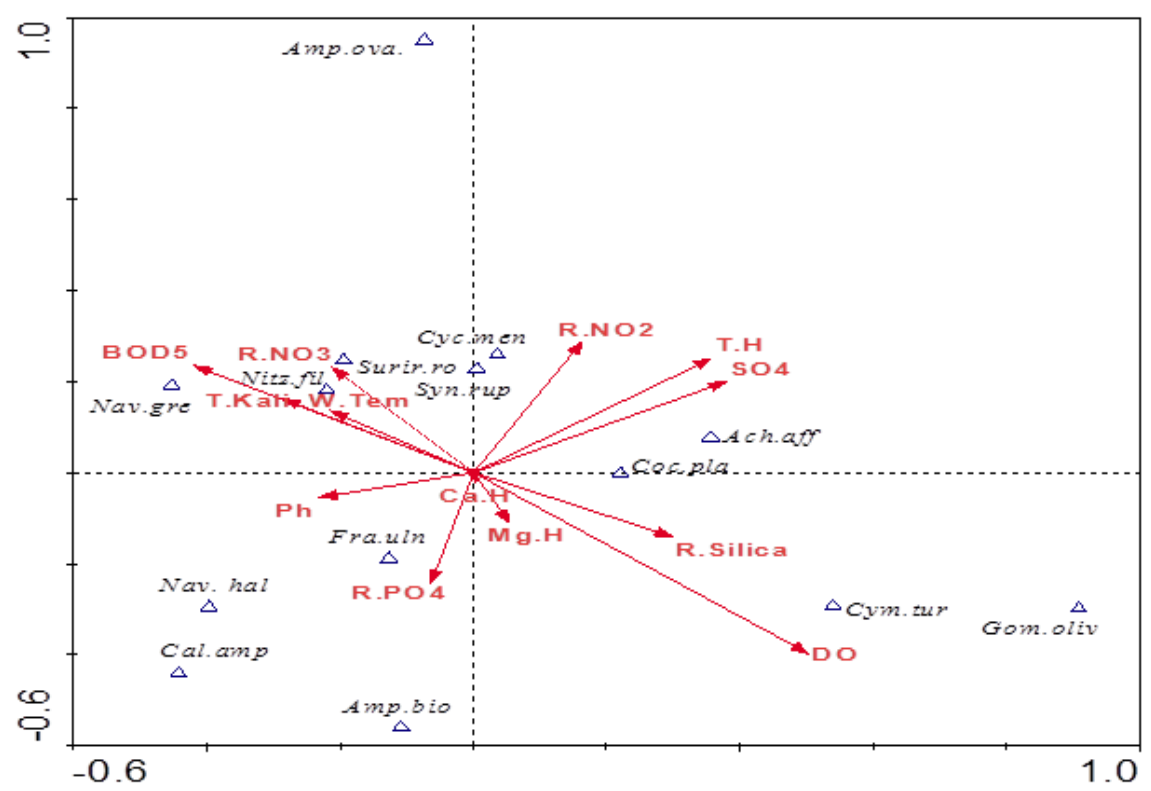

Figure 3. CCA analysis of epiphytic diatoms on (Myriophyllum alterniflorum)) and the environmental correlations during the study period of the Tigris river

\section{REFERENCES}

1. Ahmed, A. and M. A. Alflasane. 2004. Ecological studies of the River padma at Ghat, Munshiganj- II. Primary productivity, phytoplankton standing crops and diversity. Pakistan J. of Biolo. Sci. 7(11): 1870-1875

2. Al-Bayati, H. I. A. 2016. Seasonal Variations in Species Composition of Epiphytic Algae on Different Parts of Phragmites australis in the Tigris RiverBaghdad/Iraq. M.Sc. Thesis. College of Science for Women, University of Baghdad 3. Algarte, V.M, N.S., Siqueira, E.A, Murakani, and L. Rodrigues, 2009. Hydrological regime and connectively on the internnual variation in taxonomic similarity of periphytic algae. Braz. J. Bio. 62(2, suppl.):606-616

4. Al-Hassany, J.S. and H. E. Al-Bayati 2017. Screening of epiphytic algae on the aquatic plant Phragmites australis inhabiting Tigris River in Al-Jadria Site, Baghdad, Iraq. Baghdad J. of Sci., 14 (1): 85-98

5. Al-Hassany, JS, Z. AL Zahraw, A.Murtadeh and N. Sulaaiman. 2010 . Study of the effect of Himreen dam on the phytoplankton diversity in Dyala River, Iraq. JEP.3(8): 940948.

6. Al-Janabi, Z. Z. F. 2011. Application of Water Quality Indices for Tigris River within Baghdad city- Iraq. M.Sc. Thesis. College of Science for Women, University of Baghdad. pp:162
7. Al-Nimma, B.A. 1982. A study on the Limnology of the Tigris and Euphrates Rivers. M.Sc. Thesis, University of Salahulddin

8. Al-Rubyee, A. Y. M. 2002. Environmental Pollution of Students of the Third Stage. Dar Al- Kuttab For Printing and publication, Baghdad

9. Ali, F.S., R. A. bdul-Jabar and F. M Hassan. 20186. Diversity measurement indices of diatom communities in the Tigris river within Wasit province, Iraq. Baghdad Science Journal. 15 (2): 117-122

10. Al-Saboonchi, A. A.and H. N. AlManshed, 2012. Study of epiphytic algae on Ceratophyllum demersum L. from two station At Shatt AL-Arab River. J.Thi-Qar Sci. 3(2) :57-63

11. AL-Saeady, R. N. Q. 2014. An Ecological Study of Epiphytic Algae on Aquatic Macrophytes in Tigris River within Baghdad city/ Iraq. M.Sc. Thesis. College of Science for Women, University of Baghdad. pp: 165 12. Al-Shawi, E. J, A. A. Al-Rubaie, and S. B. Abdullah. 2007. A study of the ideology of the Southern part of the Tigris and Euphrates Rivers and their impact on the physical and chemical properties of the Shatt al-Arab. J. of the University Teacher, 6 (11): 125-136

13. APHA, American Public Health Association. 2005. Standard Methods for the Examination of Water and Wastewater, $21^{\text {st }}$ ed. Washington, DC. pp: 22621 
14. Crance, J. and M.Masser, 1995. Streams: A National Heritage worth Preserving. The Alabam Coorporative Extension system, ANR-911.pp: 19

15. Gaiser, E.E., P.V., McCormick, S.E. Hagerthey, and A.D. Gottlieb 2011. Landscape patterns of periphyton in the Florida Everglades. Critical Reviews in Environmental Science and Technology. 41: 92-120

16. Goldman, C. R., and A. J. Horne, 1983. Limnology. McGraw-Hill. pp: 464

17. Hadi, R.A.M. 1981. Algal studies of the River USK. Ph.D. thesis, University. College Cardiff. pp : 364

18. Hassan, F.M., J. M., Salman, F. M. Alkam, and H. J. Jawad, 2014. Ecological observation on epiphytic algae in Euphrates river at Hindiya and Manathira, Iraq. International Journal of Advanced Research, 2(4):11831194

19. Hassan, F. M., R. A., Hadi, T. I. Kassim, and J. S. Al- Hassany, 2012. Systematic study of epiphytic algal after restoration of AlHawizah marshes, Southern of Iraq . Int. J. Aquat. Sci. 3 (1): 37-57

20. Hassan, F. M., W. D., Taylor, M.M.S. AlTaee and H. J. J. Al-Fatlawi, 2010. Phytoplankton Composition of Euphrates River in Al-Hindiya Barrage and Kifil city region of Iraq. J. of Environ. Bio. 31: 343-350. 21. Hassan, F. M., J. N. A., Al-Zubaidi and O. S., Youssef. 2018. Limnological Study of Diyala River, Iraq. The Iraqi J. of Agricul. Sci., 49(3): 452-462

22. Jazaa, S.H. 2009. A Study of Physical, Chemical and Bacteriological Properties of Water of Al Kahlaa River in Maysan Governorate / Iraq. M.Sc. Thesis . College of Science. University of Basrah. pp: 67

23. Leelahakrie, K.P. and Y. Peerapornpisal, 2010. Diversity of Benthic Diatoms and Water Quality of the Ping River Northern Thailand. The International Journal Published by the Thai Society of High Education Institutes on Environment, Environ. Asia.3:82-94

24. Lowe, R. 1. 1974. Environmental Requirements and Pollution Tolerance of Freshwater Diatoms. U.S.Environmental Protection Agency, Cincinnat, Ohio. pp: 334 25. Maitland, F.S. 1978. Biology of Freshwater. Black and Son Limited,Glasgow. pp: 244.
26. Parsons, T.R., Y., Maita, and C.M. Lalli, 1984. A Manual of Chemical and Biological Methods for Seawater Analysis Pergamon Press, Oxford. pp: 173

27. Salman, J. M., F. M. Alkam, and H. J. AlFatlawi. 2012. A Biodiversity of Phytoplankton in Euphrates River, Middle of Iraq. Iraqi Journal of Science, Special Issue $1^{\text {st }}$ Conference of Biology, University of Baghdad, 6-7 March 2012, pp: 277-293

28. Salman J. M., Jawad H.J., Nassar A.J. and F. M. Hassan. 2013. A study of phytoplankton communities and related environmental factors in Euphrates river (between two cities: AlMusayyab and Hindya), Iraq. Journal of Environmental Protection, 4: 1071-1079

29. Salman, J. M., F. M. Hassan S. J. Hadi, and A. A. Motar. 2014. An ecological study of epiphytic algae on two aquatic macrophytes in lotic ecosystem. Asian Journal of Natural and Applied Sciences, 3 (3): 37-52

30. Salman, J. M. and S. J. Hadi, 2015. Environmental study of epiphytic algae on some aquatic plants in Al-Abasiya River, Iraq. Mesop. Environ. J. (3): 1-15

31. Sharplrey, A. 2005. Managing phosphorus agriculture and the environmental. College of Science, the Pennsylvania state university. pp: 8

32. Strickland, J. D. H. and T. R. Parsons, $2^{\text {nd }}$ ed. 1972. A Practical Handbook of Seawater Analysis. $2^{\text {nd }}$ ed. Bulletin Fisheries Research Board of Canada. pp: 311

33. Todd, D. K. 1980. Groundwater Hydrology. J. Wiley and Sons. Inc., New York. pp: 336

34. Tomas, W. E. 2007. The Role of Wave Disturbance on Lentic, Benthic Algae Community Structure and Diversity. M.Sc. Thesis, Bowling Green State University, Bowling Green. pp:46

35. Wetzel, R. G. and G. E. Likens, 2000. Limnological analyses, $3^{\text {rd }}$ ed., Springer. San Francisco, New York, London. pp: 429

36. Whitton, B. A. 1975. River Ecology. Blackwell scientific publications, Oxford. pp: 725. 